\title{
Steroid hormones and embryo development in ovariectomized hamsters
}

\author{
Jayasree Sengupta, Bibhas C. Paria and S. K. Manchanda \\ Department of Physiology, All India Institute of Medical Sciences, New Delhi 110029, India
}

\begin{abstract}
Summary. Preimplantation embryo development was arrested at the premorula stage in hamsters ovariectomized on Day 1 of pregnancy. This effect was reversed when $500 \mu \mathrm{g}$ progesterone were administered daily. Oestradiol-17 $\beta$ given alone had no significant effect on the cleavage rate or blastocyst formation, but a synergistic response was evident when a suboptimal $(30 \mu \mathrm{g})$ dose of progesterone was given with $50 \mathrm{ng}$ oestradiol-17 $\beta$. Cholesterol and hydrocortisol had no effect on embryo development.
\end{abstract}

\section{Introduction}

After fertilization the mammalian embryo undergoes a series of changes which allow rapid cellular proliferation and differentiation leading to the formation of the blastocyst. Intrinsic and extrinsic factors influencing preimplantation development have been described (Johnson, 1979), but little is known about the involvement of the steroid hormones that are present in oviducal and uterine fluids. In some species, such as the rat (Cochrane \& Meyer, 1957), mouse (Smithberg \& Runner, 1960) and rabbit (Hafez, 1964), blastocyst formation occurred in animals ovariectomized early in pregnancy. However, Roblero \& Garavagno (1979) have reported that in ovariectomized mice there is a need for oestradiol and progesterone in synchronizing embryo transport and cleavage rates with the physiological state of the reproductive tract. No reports are available on the hormonal requirements for embryo development and blastocyst formation in the hamster.

\section{Materials and Methods}

Sexually mature virgin golden hamsters (Mesocricetus auratus) of 80-120 g body weight were maintained in $14 \mathrm{~h} \mathrm{light} / 24 \mathrm{~h}$, lights being on from $05: 00$ to 19:00 h. Animals showing 2-3 consecutive regular cycles were paired with fertile males and when the presence of spermatozoa in the vagina the next day confirmed mating this was designated Day 1 of pregnancy. On the same day the animals were randomly assigned to a group and treated as indicated.

Group 1: these hamsters were left intact as controls.

The hamsters in Groups 2-9 were bilaterally ovariectomized between 15:00 and 16:00 h on Day 1 under semi-sterile conditions after being anaesthetized with pentobarbitone sodium (Abbott Laboratories, India) (see Sengupta, Paria \& Manchanda, 1981). Hormones were administered by subcutaneous injection in $0 \cdot 1 \mathrm{ml}$ peanut oil immediately after the operation.

Group 2 hamsters were injected with $0.1 \mathrm{ml}$ peanut oil only.

Group 3. Animals in 3 subgroups were injected daily for 3 days with (A) 25 , (B) 50 or (C) $75 \mathrm{ng}$ oestradiol-17 $\beta$ (Sigma, St Louis, U.S.A.).

Group 4 hamsters received daily injections for 3 days of (A) 30 , (B) 100 or (C) $500 \mu \mathrm{g}$ progesterone (Sigma). 
Group 5: the hamsters were injected daily for 3 days with $30 \mu \mathrm{g}$ progesterone and on the afternoon of Day 3 received (A) 25 , (B) 50 or (C) $75 \mathrm{ng}$ oestradiol-173.

Group 6. Each animal was given $2500 \mu \mathrm{g}$ progesterone daily for 3 days.

Group 7. Each hamster was treated with $2500 \mu \mathrm{g}$ medroxyprogesterone acetate (MPA; Sigma Co.) on Day 1.

Group 8. Each animal was injected with $2500 \mu \mathrm{g}$ cholesterol (E. Merck, Darmstadt, West Germany) daily for 3 days.

Group 9. Each hamster was given $2500 \mu \mathrm{g}$ hydrocortisol (Glaxo Laboratories, India) daily for 3 days.

The numbers of animals in each group are shown in Table 1; 6 hamsters from Groups 1 and 2 were killed on Day 3 at $15: 00 \mathrm{~h}$ and the oviducts and uteri were flushed with sterile saline $(0.9 \%$ $(\mathrm{w} / \mathrm{v}) \mathrm{NaCl}$ ) to recover embryos whose stage of development was recorded. The remaining animals were killed on Day 4 between $08: 00$ and $09: 00 \mathrm{~h}$. Embryos were recovered by flushing the uterus with sterile saline and the numbers of premorulae ( 8 cells or fewer), morulae and blastocysts recovered from each animal were recorded. A preimplantation embryo showing compacted cells and having no blastocoele was identified as morula, while a blastocyst had a defined cavity, inner cell mass and trophoblast cells. Blastocysts were treated with sodium citrate $(0 \cdot 25 \%)$, fixed in

Table 1. Effect of ovariectomy (Ovex), oestradiol-17 $\left(\mathrm{E}_{2}\right)$, and progesterone (P), medroxyprogesterone acetate (MPA), cholesterol and hydrocortisol on preimplantation embryo development in the hamster

\begin{tabular}{|c|c|c|c|c|c|c|c|c|}
\hline \multirow[b]{2}{*}{ Group } & \multirow[b]{2}{*}{ Treatment } & \multirow{2}{*}{$\begin{array}{l}\text { No. of } \\
\text { hamsters }\end{array}$} & \multicolumn{5}{|c|}{ No. of embryos recovered $(\%)$} & \multirow{2}{*}{$\begin{array}{c}\text { Mean } \pm \text { s.e.m. } \\
\text { no. of } \\
\text { blastomeres/ } \\
\text { blastocyst (no.) }\end{array}$} \\
\hline & & & Total & $\leqslant 8$-cell & Morula & Blastocyst & Degenerated & \\
\hline 1 & Control & 10 & $85^{\mathrm{a}}$ & - & $2(2 \cdot 3)$ & $83(97 \cdot 7)$ & - & $30 \cdot 54 \underset{(22)}{ \pm} 0.60^{1}$ \\
\hline 2 & Ovex & 20 & $69^{\mathrm{b}}$ & $60(86 \cdot 9)$ & - & - & $9(13 \cdot 1)$ & - \\
\hline 3 & Ovex & & & & & & & \\
\hline A & $25 \mathrm{ng} \mathrm{E}_{2}$ & 9 & $29^{c}$ & $5(17 \cdot 2)$ & $3(10 \cdot 4)$ & - & $21(72 \cdot 4)$ & 一 \\
\hline $\mathbf{B}$ & $50 \mathrm{ng} \mathrm{E}$ & 11 & $37^{d}$ & $14(37 \cdot 8)$ & $11(29.8)$ & - & $12(32.4)$ & - \\
\hline $\mathrm{C}$ & $75 \mathrm{ng} \mathrm{E}_{2}$ & 9 & $33^{e}$ & $4(12 \cdot 1)$ & $5(15 \cdot 2)$ & - & $24(72 \cdot 7)$ & - \\
\hline 4 & Ovex & & & & & & & \\
\hline A & $30 \mu \mathrm{g} \mathrm{P}$ & 20 & $79^{f}$ & $21(26 \cdot 6)$ & $56(70 \cdot 9)$ & $2(2 \cdot 5)$ & - & - \\
\hline B & $100 \mu \mathrm{g} \mathrm{P}$ & 20 & $73 \mathrm{~g}$ & - & $25(34 \cdot 3)$ & $48(65 \cdot 7)$ & - & $25 \cdot 19 \underset{(23)}{ \pm} 0 \cdot 78^{m}$ \\
\hline $\mathrm{C}$ & $500 \mu \mathrm{g} P$ & 20 & $85^{\mathrm{h}}$ & - & $5(5 \cdot 9)$ & $80(94 \cdot 1)$ & - & $30 \cdot 86 \pm 0.61^{n}$ \\
\hline 5 & Ovex & & & & & & & \\
\hline $\mathbf{A}$ & $30 \mu \mathrm{g} \mathbf{P}+25 \mathrm{ng} \mathbf{E}_{2}$ & 26 & $99^{i}$ & $50(50 \cdot 5)$ & $6(6 \cdot 1)$ & $34(34 \cdot 3)$ & $9(9 \cdot 1)$ & $24.48 \underset{(23)}{ \pm} 0.80^{\circ}$ \\
\hline B & $30 \mu \mathrm{g} P+50 \mathrm{ng} E_{2}$ & 24 & $96^{j}$ & $3(3 \cdot 1)$ & $12(12 \cdot 5)$ & $73(76 \cdot 1)$ & $8(8 \cdot 3)$ & ${ }_{(20)}^{27.80 \pm 0.67 p}$ \\
\hline $\mathrm{C}$ & $30 \mu \mathrm{g} P+75 \mathrm{ng} \mathrm{E}_{2}$ & 26 & $102^{\mathrm{k}}$ & $26(25 \cdot 5)$ & $16(15 \cdot 7)$ & $37(36 \cdot 3)$ & $23(22 \cdot 5)$ & $24 \cdot 85 \pm \underset{(20)}{ } 0 \cdot 70^{9}$ \\
\hline 6 & Ovex & & & & & & & \\
\hline & $2.5 \mathrm{mg} \mathrm{P}$ & 8 & $42^{r}$ & - & $4(9 \cdot 5)$ & $38(90 \cdot 5)$ & - & $\begin{array}{c}31 \cdot 3 \pm 1 \cdot 2^{v} \\
(24)\end{array}$ \\
\hline 7 & Ovex & & & & & & & \\
\hline & $2.5 \mathrm{mg}$ MPA & 16 & $68^{s}$ & $3(4 \cdot 4)$ & $7(10 \cdot 3)$ & $58(85 \cdot 3)$ & - & $\begin{array}{c}27 \cdot 7 \pm 0 \cdot 88^{w} \\
(20)\end{array}$ \\
\hline 8 & Ovex & & & & & & & \\
\hline & $2.5 \mathrm{mg}$ cholesterol & 11 & $51^{t}$ & $48(94 \cdot 1)$ & $2(3.9)$ & - & $1(2 \cdot 0)$ & - \\
\hline 9 & Ovex & & & & & & & \\
\hline & $2.5 \mathrm{mg}$ hydrocortisol & 12 & $53^{\mathrm{u}}$ & $46(86 \cdot 8)$ & $3(5 \cdot 7)$ & - & $4(7 \cdot 5)$ & - \\
\hline
\end{tabular}

The superscript letters indicate the following interactions: a-j, g-i, g-k, h-j, $P<0.01$; g-j, o-p, p-q, v-w, $P<0.05$; a-b, a-c, a-f, a-g, a-h, a-i, b-g, b-h, b-i, f-i, h-i, l-m, m-n, n-p, r-t, r-u, s-t, s-u, $P<0 \cdot 001$. 
ethanol : acetic acid $(3: 1 \mathrm{v} / \mathrm{v})$ and then stained with Giemsa (Sigma Co.) to count the blastomeres (Tarkowski, 1966).

The $\chi^{2}$ test was used to compare the mean number of blastocysts found in the different groups and Student's $t$ test to compare the mean number of blastomeres per embryo.

\section{Results}

Preimplantation embryos at the 6- to 8-cell stage $(\mathrm{N}=42)$ were obtained from the uterine flushings of Group-1 hamsters killed at 15:00 h on Day 3; the oviducts did not contain any embryos. In the Group-2 hamsters killed on Day 3 there were 26 6-8-cell embryos in the uterine flushings. The remaining results are given in Table 1 .

Ovariectomy in hamsters inhibited embryo development. Treatment with graded doses of oestradiol-17 $\beta$ resulted in no significant improvement in embryo development except in hamsters in Group 3B which had fewer $(P<0.01)$ degenerated embryos than did those in Subgroups $A$ and C. The Group 4 results showed a dose-dependent response for progesterone. A synergistic response on embryo development was seen with a suboptimal dose of progesterone and graded dosages of oestradiol-17 $\beta$ : maximal response occurred with $50 \mu \mathrm{g}$ oestradiol-17 $\beta$ and $30 \mu \mathrm{g}$ progesterone (Group 5). High doses of progesterone or medroxyprogesterone acetate (Groups 6 and 7) significantly $(P<0.001)$ stimulated blastocyst formation. Cholesterol or hydrocortisol (Groups 8 and 9) did not stimulate development and the embryos remained mostly at the 8-cell stage. The overall low recovery rate of preimplantation embryos from Groups 2 to 9 may have been due to ovariectomy being performed on these animals on Day 1 of pregnancy which may have led to loss of some embryos from the oviducts.

The effects of the treatments on embryo cleavage rate are also shown in Table 1. The cleavage rate was similar to that of the intact control hamsters (Group 1) only in Group $4 \mathrm{C}$; values in all the other groups were lower $(P<0.05)$.

\section{Discussion}

The results of the present study show that ovariectomy of hamsters arrested embryo development at the premorula, 6- to 8-cell, stage; embryo transport through the oviduct remained normal and the numbers of embryos recovered from the uterus on the afternoon of Day 3 were comparable with those in intact animals. Progesterone at a dose of $500 \mu \mathrm{g}$ was required to support cell cleavage and differentiation of embryonic cells during the preimplantation period. Orsini \& Meyer (1962) reported that at least $500 \mu \mathrm{g}$ progesterone were required to induce normal numbers of implantations. We obtained similar results. Oestradiol-17 $\beta$ given alone to ovariectomized hamsters had no significant effects on development and cleavage rate of embryos but it did potentiate the action of a low dose of progesterone in these processes. Embryo development and blastocyst formation in rats, mice and rabbits (Cochrane \& Meyer, 1957; Smithberg \& Runner, 1960; Hafez, 1964) can occur in the absence of oestrogen and progesterone, but shedding of the zona pellucida was considerably delayed in ovariectomized rats (Dickmann, 1968), and oviducal transport, cleavage rate and transformation from morula to blastocyst were stimulated in mice by a synergistic action of oestrogen and progesterone (Roblero \& Garavagno, 1979). The hamster, however, shows a total dependence on progesterone for stimulating development beyond the 8-cell stage. The metabolic requirements for hamster embryo development at this critical 8-cell stage remain unknown; progesterone may accelerate the metabolism of the embryo by stimulating secretory processes in the oviduct and uterus. Noske \& Daniel (1974) have reported the presence of a specific protein in the uterine fluid of hamsters on Day 3 of pregnancy. Progesterone stimulates uteroglobin synthesis through transcriptional and non-transcriptional mechanisms (Loosfelt, Fridlansky, Atger 
\& Milgrom, 1981). It is also possible that progesterone acts directly on embryonic cells, perhaps by providing a precursor for oestrogen synthesis (see Dickmann \& Sengupta, 1974).

This study was supported by funds received from the Indian Council of Medical Research and the Family Planning Foundation of India. We thank Dr H. M. Weitlauf, University of Oregon, for helpful suggestions.

\section{References}

Beier, H.M., Kuhnel, W. \& Petry, G. (1970) Uterine secretion proteins as extrinsic factors in preimplantation development. Adv. Biosci. 6, 165-189.

Cochrane, R.L. \& Meyer, R.K. (1957) Delayed nidation in the rat induced by progesterone. Proc. Soc. exp. Biol. Med. 96, 155-159.

Dickmann, Z. (1968) Does shedding of the zona pellucida by the rat blastocyst depend on stimulation by the ovarian hormones? J. Endocr. 40, 393-394.

Dickmann, Z. \& Sengupta, J. (1974) $\Delta^{5}-3 \beta$-Hydroxysteroid dehydrogenase and oestradiol-17 $\beta$ hydroxysteroid dehydrogenase activity in preimplantation hamster embryos. Devl Biol. 40, 196-198.

Hafez, E.S.E. (1964) Growth and survival of blastocysts in the domestic rabbit. II. Quantitative effects of exogenous progesterone following ovariectomy. $J$. Reprod. Fert. 7, 241-242.

Johnson, M.H. (1979) Intrinsic and extrinsic factors in preimplantation development. J. Reprod. Fert. 55, 258-265.

Loosfelt, H., Fridlansky, F., Atger, M. \& Milgrom, E. (1981) A possible nontranscriptional effect of progesterone. J. Steroid Biochem. 15, 107-110.
Noske, I.G. \& Daniel, J.C., Jr (1974) Changes in uterine and oviductal fluid proteins during early pregnancy in the golden hamster. J. Reprod. Fert. 38, 173-176.

Orsini, M.W. \& Meyer, R.K. (1962) Effects of varying doses of progesterone on implantation in the ovariectomized hamster. Proc. Soc. exp. Biol. Med. 110, 713-715.

Roblero, L.S. \& Garavagno, A.C. (1979) Effect of oestradiol-17 7 and progesterone on oviductal transport and early development of mouse embryos. $J$. Reprod. Fert. 57, 91-95.

Sengupta, J., Paria, B.C. \& Manchanda, S.K. (1981) Effect of an oestrogen antagonist on implantation and uterine leucylnaphthylamidase activity in the ovariectomized hamster. J. Reprod. Fert. 62, 437440.

Smithberg, M. \& Runner, M.N. (1960) Retention of blastocysts in non-progestational uteri of mice. J. exp. Zool. 143, 21-30.

Tarkowski, A.K. (1966) An air drying method for chromosome preparations from mouse eggs. Cytogenetics 5, 394-400.

Received 22 July 1982 